\title{
Physicochemical composition and FTIR characterization of castor seed oil
}

\section{Tarique Panhwar ${ }^{1}$, Sarfaraz Ahmed Mahesar' ${ }^{1}$, Aftab Ahmed Kandhro, Syed Tufial Hussain Sheerazi ${ }^{1}$, Abdul Hameed Kori ${ }^{1}$, Zahid Hussain Laghari ${ }^{1}$, Jamil-ur-Rehman Memon ${ }^{2}$}

\section{1 - National Centre of Excellence in Analytical Chemistry, University of Sindh, Pakistan 2 - Dr. M. A. Kazi Institute of Chemistry, University of Sindh, Pakistan}

Keywords:

Oil

Castor

Seed

FTIR

Article history:

Received 14.02.2019

Received in revised form 25.08.2019

Accepted 28.11.2019

Corresponding author:

Tarique Panhwar

E-mail:

panhwertarique@

gmail.com

DOI: $10.24263 / 2304-$

974X-2019-8-4-9

\section{Abstract}

Introduction. This paper provides the complete profile of physicochemical properties and fatty acid composition of local castor varieties from Sindh, Pakistan. Initially, physical characteristics of seeds were studied followed by detailed examination of oil.

Materials and methods. Oil was extracted through Soxhlet extraction method followed by physico-chemical examination of necessary parameters (iodine value, peroxide value, saponification value, viscosity and moisture). For qualitative analysis of castor oil GCMS and FTIR instruments were used.

Results and discussions. Oil content was observed in the range of 44-48\%. Moisture and ash content of castor seeds were found to be $4.22-5.16 \%$ and $5.66-6.49 \%$, respectively. Compositional analysis by GCMS has shown ricinoleic acid (88.5-93.1\%) as a prominent fatty acid in all local varieties. Other fatty acids present were palmitic $(0.4-$ $0.8 \%)$, stearic $(0.8-1.0 \%)$, linoleic $(2.8-3.3 \%)$, and ecosenoic $(0.2-1.5 \%)$. Free fatty acid value of all castor oil varieties was found to be in the range of $0.16-0.53 \%$. Other quality parameters such as IV, PV and SV of different castor oil varieties were determined in the range of 79.16$90.03 \mathrm{gI}_{2} / 100 \mathrm{~g}, 1.62-1.89 \mathrm{meq} / \mathrm{Kg}$, and $188.12-204.76$ $\mathrm{mgKOH} / \mathrm{g}$, respectively. The FTIR spectra of castor seed oil varieties were nearly similar. On careful examination of the intensity values of each functional group present in the oil showed some variations in castor seed varieties.

Conclusion. Indigenous local varieties of castor with sufficient oil content (>40\%) were explored and examined for some important parameters. FTIR band intensities of some functional groups highly correlated with important parameters of castor oil. 


\section{Introduction}

Castor is one of the most promising non-edible oil seed crop with great industrial importance, grown all over the world in warm temperate, tropical and subtropical regions [1]. Castor belongs to Eurphorbiaceae family and botanically known as Ricinus Communis L. [2]. The purpose of cultivation of castor plant is because of its seeds that have high oil content. The oil is pale yellow in color, viscous in nature with a lot of applications in industrial and medicinal fields [3].

Since the fatty acid composition consists of about $90 \%$ ricinoleic acid and other fatty acids include oleic acid $2.8 \%$, palmitic acid $0.7 \%$, stearic acid $0.9 \%$, linoleic acid $4.4 \%$, and linolenic acid $0.2 \%$ [4]. The unique properties of castor oil among other vegetable oils are due to the ricinoleic acid (a unique fatty acid $\mathrm{C}_{18} \mathrm{H}_{34} \mathrm{O}_{3}$ ) known as cis-12-hydroxyoctadeca9-enoic acid. Castor oil has relatively high viscosity, specific gravity and solubility in alcohols due to high hydroxyl value in the nature [5].

Castor oil is widely used as a raw ingredient in the manufacture of pharmaceuticals, cosmetics, coatings, soap, nylon, lubricants, dyes, inks, and waxes [6]. More over castor oil is used in various industrial fields as a potential by product [7]. Castor oil has limited food value and do not compete with food crops [3]. It is mainly cultivated for trading purpose in more than 30 countries of the world in the area of 1.525 million hectares, which produce 1.58 million tons of seed. Major castor growing countries are India, Brazil, China, Thailand, Russia, Ethiopia and Philippines [8]. India has major contribution of $65 \%$ of castor oil all over the world, thus fulfils 80 to $90 \%$ of world's requirement of ricinus oil [1].

Pakistan is agricultural country with $70 \%$ population belongs to an agriculture sector [9]. Pakistan has total area of 79.6 million hectares, $70 \%$ of which is arid to semi-arid. The total unused land is about 28 million hectares, due to shortage of water, severe heat and saline nature of soil, the large area of land is unproductive $[9,10,11]$ and therefore castor plant has potential to grow on marginal lands as compared to other non-edible oil yielding plants [12].

A sufficient research work has been reported on physicochemical characteristics of castor oil [2,13] and its fatty acid composition [5]. However, a limited work is done on searching new varieties of castor seed for complete profiling. The current study presents some more aspects to study new castor varieties, which include complete profiling of castor seed in the light of environmental factors such as light, altitude, latitude and soil type. Furthermore, FTIR study was also carried out to characterize castor oil and correlated with the physiochemical properties.

\section{Materials and methods}

\section{Reagents and sample collection}

All the chemicals and reagents used in the present work were purchased from E-Merck (Darmstadt, Germany). Castor beans were collected from fifteen different locations of Sindh province. Some harvesting sites had different environmental conditions and soil types. Five locations were selected within the same environmental conditions. The plants at different sites showed variability in their height. Branch distribution in castor plant was ramified. Sites 1-5 belong to middle region of Sindh province, where luminosity exposure was observed. The region has low humidity with temperature of $40-50{ }^{\circ} \mathrm{C}$ throughout the growing season and type of soil was non-sodic, non-saline and alluvium in nature having more ratios of silt and clay with moderate level of water observed at sites. Sites 6-10 belong to downstream of 
Sindh province with the temperature of $35{ }^{\circ} \mathrm{C}$ with humidity of about $60 \%$. Soil was rocky, slightly saline with little water present in the area. Sites 11-15 also come in downstream with the temperature of $35^{\circ} \mathrm{C}$. Soil was fertile, non-sodic, non-saline. The collected castor seeds were broken off and packed in clean sampling bags until analysis.

\section{Classification}

Castor seeds were classified on the basis of color, plant characteristics, and seed weight. On the basis of classification, the collected castor seeds generated three new local varieties. These newer local varieties were coded as S-1, S-2 and S-3. All castor varieties were dried and cleaned in order to remove some foreign materials and stored at room temperature in the absence of light.

\section{Oil extraction}

Crude oil from castor beans was extracted by Soxhlet extraction method using n-hexane as a solvent with slight modification as reported by Akpan et al., 2006 [13]. Finely ground $10 \mathrm{~g}$ of sample were put into thimble and carefully placed inside the Soxhlet extractor, then $300 \mathrm{~mL}$ of $\mathrm{n}$-hexane was added to round bottom flask. The process continued for about $6 \mathrm{~h}$ at $65{ }^{\circ} \mathrm{C}$. After complete extraction hexane was evaporated using rotary evaporator (Buchi, Switzerland). For total oil content, weight of the extracted oil was measured using electronic balance. The oil was kept at low temperature for further physicochemical analysis.

\section{Physicochemical analysis of seed and oil}

Seed characteristics. Some physical characteristics of castor seeds of different varieties were analyzed such as seed color, weight, thickness, length and weight of 100-seeds. Specific gravity and refractive index were measured according to reported method [13].Viscosity of oil samples was measured using a viscometer (VM 3000 stabinger Anton Park, Austria) at $40^{\circ} \mathrm{C}$ using $5 \mathrm{~mL}$ of sample. Ash content was determined by AOCS (method Ba 5a-49) [14]. Moisture content measurement was done by drying up to constant weight at $105^{\circ} \mathrm{C}$ [15].

Chemical analysis. For the chemical characteristics official methods of AOCS were used for the determination of iodine value (IV method- Cd 1-25), peroxide value (PV methodCd 8-53), saponification value (SV method-Cd 3-25) and free fatty acids (FFA method- Aa 6-38)[14].

FTIR analysis of castor oil. For the qualitative analysis of castor oil, infrared (IR) spectra were recorded using FTIR spectrometer (Thermo Nicolet Avatar 330) with a DTGS detector (Thermo Nicolet Analytical Instruments, Madison, WI). The removable (ZnSe crystal) single bounce-attenuated total reflection (ATR) accessory was used for oil analysis with the conditions as follows: resolution $4 \mathrm{~cm}^{-1}$, scans 32 , IR range $4000-650 \mathrm{~cm}^{-1}$. The background spectrum was recorded before the sample analysis. After recording the spectra $\mathrm{ZnSe}$ crystal was carefully cleaned with hexane to remove any residue of the previous sample.

Determination of fatty acid composition. Fatty acid methyl esters (FAMEs) were prepared according to official IUPAC method No: 2.30 [16]. A complete profile of fatty acid composition including major and minor fatty acids was studied using GC-MS (Agilent 5975 GC-MSD) with chemstation 6890 Scale mode software. FAMEs were analyzed using Agilent autosampler 7683-B injector (Agilent Technologies, Little Fall, NY, USA), a HP-5MS (5\% phenyl methylsiloxane) capillary column with dimension of $30 \mathrm{~m}$, i.d $0.25 \mathrm{~mm}$. The initial temperature was set as $150^{\circ} \mathrm{C}$ and maintained for 2 min then raised to $220^{\circ} \mathrm{C}$ at a ramp of 3 
${ }^{\circ} \mathrm{C} / \mathrm{min}$ and finally held for 15 minutes. Carrier gas used was helium at a flow rate of 1.5 $\mathrm{mL} / \mathrm{min}$. About $2-\mu \mathrm{L}$ of FAMEs were injected into the column using split mode injection system. The mass spectrometer was operated using electron impact mode at $70 \mathrm{eV}$ in the scan range of 50-550 m/z. GC-MS chromatograms were compared with two libraries (NIST and Wily) which provided much information about major and minor fatty acids in castor oil.

\section{Statistical analysis}

Two samples of each variety (1 kg each) were collected and every sample was analyzed thrice and the obtained results were reported as mean \pm standard deviation, by using Microsoft ${ }^{\circledR}$ excel 2003 software.

\section{Results and discussion}

Table 1A shows the geographical locations of three different castor seed harvesting sites. S-1 variety was collected from sites $1-5$, S-2 variety from sites 6-10 and S-3 variety from sites 11-15. Table 1B represents physical characteristics of three different castor seed varieties. Some variations among different varieties were found; this might be due to different environmental conditions and soil types [17]. Moisture and ash content of castor seeds showed little variability as shown in Table 1B. Moisture and ash content of castor seeds were found to be $4.22-5.16 \%$ and $5.66-6.49 \%$, respectively.

Table 2 shows the proximate composition along with some quality attributes of different castor varieties. A significant variability was found in the oil content of studied castor seed varieties that ranged from $44-48 \%$. The obtained values showed less oil content than indigenous variety reported earlier [18]. Observed variations in the seed oil content may be due to castor seed genotypes, harvesting time, environmental and cultural aspects.

Refractive index, specific gravity and viscosity in castor varieties were found in the range of $1.4321-1.4532,0.9531-0.9576 \mathrm{~g} / \mathrm{cm}^{-3}$ and $663-713 \mathrm{mPas} . \mathrm{s}$, respectively. The high viscosity of castor oil is due to the presence of long chain carbon atoms which mainly consist of ricinoleic acid; a mono-saturated, 18-carbon fatty acid having hydroxyl group at $12^{\text {th }}$ carbon, a very uncommon property for a biological fatty acids which makes it unique oil from other vegetable oils.

The chemical parameters such as IV, PV and SV of different varieties were determined in the range of $79.16-90.03 \mathrm{gI}_{2} / 100 \mathrm{~g}, 1.62-1.89 \mathrm{meq} / \mathrm{Kg}$, and $188.12-204.76 \mathrm{mgKOH} / \mathrm{g}$, respectively. The quality of oil depends on the presence of FFA. Generally these values are calculated as percentage of oleic acid. In current study, the range of FFA in castor varieties was determined as $0.16-0.53 \%$. These values are almost comparable to freshly processed vegetable oils [19]. 
Site coordinates where the castor beans were harvested

Table 1A

\begin{tabular}{|c|c|c|c|}
\hline Site & Elevation $(\mathbf{m})$ & Latitude & Longitude \\
\hline 1 & 24 & $26.73^{\circ} \mathrm{N}$ & $67.78^{\circ} \mathrm{E}$ \\
\hline 2 & 42 & $26.41^{\circ} \mathrm{N}$ & $67.37^{\circ} \mathrm{E}$ \\
\hline 3 & 43 & $26.56^{\circ} \mathrm{N}$ & $67.71^{\circ} \mathrm{E}$ \\
\hline 4 & 43 & $26.86^{\circ} \mathrm{N}$ & $67.78^{\circ} \mathrm{E}$ \\
\hline 5 & 41 & $26.42^{\circ} \mathrm{N}$ & $67.86^{\circ} \mathrm{E}$ \\
\hline 6 & 38 & $25.41^{\circ} \mathrm{N}$ & $68.27^{\circ} \mathrm{E}$ \\
\hline 7 & 29 & $25.90^{\circ} \mathrm{N}$ & $68.24^{\circ} \mathrm{E}$ \\
\hline 8 & 39 & $25.35^{\circ} \mathrm{N}$ & $68.26^{\circ} \mathrm{E}$ \\
\hline 9 & 39 & $26.03^{\circ} \mathrm{N}$ & $68.13^{\circ} \mathrm{E}$ \\
\hline 10 & 38 & $25.28^{\circ} \mathrm{N}$ & $68.15^{\circ} \mathrm{E}$ \\
\hline 11 & 24 & $25.38^{\circ} \mathrm{N}$ & $68.36^{\circ} \mathrm{E}$ \\
\hline 12 & 25 & $25.42^{\circ} \mathrm{N}$ & $68.54^{\circ} \mathrm{E}$ \\
\hline 13 & 21 & $25.52^{\circ} \mathrm{N}$ & $69.01^{\circ} \mathrm{E}$ \\
\hline 14 & 22 & $25.45^{\circ} \mathrm{N}$ & $68.72^{\circ} \mathrm{E}$ \\
\hline 15 & 26 & $25.76^{\circ} \mathrm{N}$ & $68.66^{\circ} \mathrm{E}$ \\
\hline
\end{tabular}

Physical characteristics of castor seeds

Table 1B

\begin{tabular}{|c|c|c|c|c|c|c|c|c|}
\hline \multicolumn{9}{|c|}{ Mean \pm SD } \\
\hline $\begin{array}{c}\text { Seed } \\
\text { Variety }\end{array}$ & $\begin{array}{l}\text { Qualitative } \\
\text { description }\end{array}$ & $\begin{array}{c}\text { Moisture } \\
(\%)\end{array}$ & $\begin{array}{l}\text { Ash } \\
(\%)\end{array}$ & $\begin{array}{c}\text { Length } \\
(\mathrm{mm})\end{array}$ & $\begin{array}{c}\text { Thickness } \\
\text { (mm) }\end{array}$ & $\begin{array}{l}\text { Width } \\
(\mathbf{m m})\end{array}$ & $\begin{array}{c}\text { Seed } \\
\text { weight } \\
(\mathrm{g})\end{array}$ & $\begin{array}{c}\text { 100-seed } \\
\text { weight } \\
\text { (g) }\end{array}$ \\
\hline S-1 & Brownish & $\begin{array}{c}4.22 \\
\pm 0.21 \\
\end{array}$ & $\begin{array}{c}5.88 \\
\pm 0.23 \\
\end{array}$ & $\begin{array}{l}11.55 \\
\pm 0.39 \\
\end{array}$ & $\begin{array}{c}5.47 \\
\pm 0.40 \\
\end{array}$ & $\begin{array}{c}7.62 \\
\pm 0.31 \\
\end{array}$ & $\begin{array}{c}0.40 \\
\pm 0.08 \\
\end{array}$ & $\begin{array}{r}38.86 \\
\pm 0.14 \\
\end{array}$ \\
\hline $\mathrm{S}-2$ & $\begin{array}{l}\text { Light } \\
\text { brown }\end{array}$ & $\begin{array}{c}5.16 \\
\pm 0.15\end{array}$ & $\begin{array}{c}6.49 \\
\pm 0.19\end{array}$ & $\begin{array}{l}12.19 \\
\pm 1.02\end{array}$ & $\begin{array}{c}5.20 \\
\pm 0.50\end{array}$ & $\begin{array}{c}7.21 \\
\pm 0.96\end{array}$ & $\begin{array}{c}0.34 \\
\pm 0.04\end{array}$ & $\begin{array}{l}35.18 \\
\pm 0.20\end{array}$ \\
\hline$S-3$ & $\begin{array}{l}\text { Reddish } \\
\text { brown }\end{array}$ & $\begin{array}{c}4.46 \\
\pm 0.12\end{array}$ & $\begin{array}{c}5.66 \\
\pm 0.12\end{array}$ & $\begin{array}{l}12.55 \\
\pm 1.49\end{array}$ & $\begin{array}{c}6.10 \\
\pm 0.75\end{array}$ & $\begin{array}{c}7.88 \\
\pm 0.58\end{array}$ & $\begin{array}{c}0.48 \\
\pm 0.12\end{array}$ & $\begin{array}{l}39.60 \\
\pm 0.10\end{array}$ \\
\hline
\end{tabular}

Table 2

Proximate composition and quality attributes of castor varieties

\begin{tabular}{|c|c|c|c|c|c|c|c|c|}
\hline Variety & $\begin{array}{c}\text { Oil } \\
\text { content } \\
\%\end{array}$ & $\begin{array}{c}\text { Specific } \\
\text { gravity } \\
\text { at } 28{ }^{\circ} \mathrm{C} \\
\left(\mathrm{g} / \mathrm{cm}^{-3}\right)\end{array}$ & $\begin{array}{l}\text { Viscosity } \\
\text { at } 28{ }^{\circ} \mathrm{C} \\
\text { (mPas.s) }\end{array}$ & $\underset{{ }^{\circ} \mathrm{C}}{\mathrm{RI} \text { at } 28}$ & $\begin{array}{c}\text { FFA } \\
\%\end{array}$ & $\begin{array}{c}\text { IV } \\
\mathrm{gI}_{2} / 100 \mathrm{~g}\end{array}$ & $\begin{array}{c}\text { PV } \\
\text { meq/Kg }\end{array}$ & $\begin{array}{c}\text { SV } \\
\text { mgKOH/g }\end{array}$ \\
\hline S-1 & $\begin{array}{c}48 \\
\pm 1.21\end{array}$ & $\begin{array}{c}0.9531 \\
\pm 0.02\end{array}$ & $\begin{array}{c}681 \\
\pm 9.11\end{array}$ & $\begin{array}{l}1.4321 \\
\pm 0.05\end{array}$ & $\begin{array}{c}0.16 \\
\pm 0.006\end{array}$ & $\begin{array}{l}80.34 \\
\pm 1.55\end{array}$ & $\begin{array}{c}1.89 \\
\pm 0.05\end{array}$ & $\begin{array}{l}197.35 \\
\pm 1.81\end{array}$ \\
\hline S-2 & $\begin{array}{c}44 \\
\pm 1.38 \\
\end{array}$ & $\begin{array}{c}0.9576 \\
\pm 0.03 \\
\end{array}$ & $\begin{array}{c}713 \\
\pm 8.59 \\
\end{array}$ & $\begin{array}{l}1.4385 \\
\pm 0.04 \\
\end{array}$ & $\begin{array}{c}0.27 \\
\pm 0.01 \\
\end{array}$ & $\begin{array}{l}90.03 \\
\pm 1.33 \\
\end{array}$ & $\begin{array}{c}1.87 \\
\pm 0.06 \\
\end{array}$ & $\begin{array}{c}204.76 \\
\pm 2.13 \\
\end{array}$ \\
\hline S-3 & $\begin{array}{c}46 \\
\pm 1.22 \\
\end{array}$ & $\begin{array}{c}0.9563 \pm \\
0.01\end{array}$ & $\begin{array}{c}663 \\
\pm 8.87 \\
\end{array}$ & $\begin{array}{l}1.4532 \\
\pm 0.06 \\
\end{array}$ & $\begin{array}{c}0.53 \\
\pm 0.02 \\
\end{array}$ & $\begin{array}{l}79.16 \\
\pm 1.12 \\
\end{array}$ & $\begin{array}{c}1.62 \\
\pm 0.03 \\
\end{array}$ & $\begin{array}{l}188.12 \\
\pm 1.93 \\
\end{array}$ \\
\hline
\end{tabular}


Knowledge of fatty acid profile is much essential for industrial sectors including energy, cosmetic and soap making industries [20]. Table 3 represents the fatty acid composition of extracted oil of castor seed varieties. Analysis showed that the most abundant fatty acid in each variety was ricinoleic acid; found as $88.5 \%, 90.9 \%$ and $93.1 \%$ respectively in $\mathrm{S}-1, \mathrm{~S}-2$ and S-3. Other fatty acids present were palmitic (0.4-0.8\%), stearic (0.8-1.0\%), linoleic (2.8$3.3 \%)$, and ecosenoic $(0.2-1.5 \%)$. Three different isomers of oleic acid were also detected in castor varieties such as oleic n-9 (2.6-4.3\%), oleic n-10 (0.4-0.5\%), and isomeric oleic n-11 was also found at $0.2 \%$. Ricinoleic acid is the prominent fatty acid found in castor varieties. The obtained values of this unique fatty acid are even higher than Malaysian (84.2\%), Egyptian (81.9\%), and Brazilian (90.2\%) castor varieties. Whereas all studied varieties showed lower recinoleic acid content than Indian castor varieties. Presence of high content of ricinoleic acid represents good quality of oil.

Table 3

Fatty acid composition of extracted castor seed oil from three varieties of Sindh Pakistan

\begin{tabular}{|c|c|c|c|c|c|c|c|c|}
\hline Variety & $C_{16: 0}$ & $C_{18: 0}$ & $C_{18: 1 n 9}$ & $C_{18: 1 n 10}$ & $C_{18: 1 n 11}$ & $C_{18: 2 n 9,12}$ & $C_{20: 1 n 11}$ & $C_{18: 1 n 9,12-\mathrm{OH}}$ \\
\hline S-1 & $0.8 \pm 0.02$ & $0.9 \pm 0.01$ & $4.3 \pm 0.1$ & $0.5 \pm 0.02$ & - & $3.3 \pm 0.1$ & $1.5 \pm 0.05$ & \\
\hline S-2 & & & $3.8 \pm$ & & 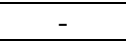 & & - & \\
\hline S-3 & $0.4 \pm 0.01$ & $0.8 \pm 0.02$ & $2.6 \pm 0.1$ & - & $0.2 \pm 0.01$ & $2.8 \pm 0.09$ & $0.2 \pm 0.01$ & $93.1 \pm 3.3$ \\
\hline
\end{tabular}

Table 4 represents the comparative data of fatty acid profile of current varieties with Malaysian, Indian, Brazilian, Egyptian and indigenous castor variety from this region. The two fatty acids including isomers of oleic acid (C18:1 n10) and ecosenoic acid (C20:1 n11) were present in indigenous varieties but both were absent in varieties of other countries. The total unsaturated fatty acid content was higher than Malaysian, Brazilian, Indian and Egyptian varieties.

Table 4

Comparison of fatty acid composition of castor varieties with world varieties

\begin{tabular}{|l|c|c|c|c|c|c|}
\hline \multicolumn{1}{|c|}{ Fatty acid (\%) } & $\begin{array}{c}\text { Current } \\
\text { Study }\end{array}$ & Indigineous $^{\mathbf{a}}$ & Malaysia $^{\mathbf{b}}$ & Brazil $^{\mathbf{c}}$ & India $^{\mathbf{d}}$ & Egypt $^{\mathbf{e}}$ \\
\hline Palmitic; $\mathrm{C}_{16: 0}$ & $0.4-0.8$ & 0.31 & 1.3 & 0.7 & - & 1.6 \\
\hline Stearic; $\mathrm{C}_{18: 0}$ & $0.8-1.0$ & 0.45 & 1.2 & 0.9 & 1.0 & 3.4 \\
\hline Oleic; $\mathrm{C}_{18: 1 \mathrm{n} \text { }}$ & $2.6-4.3$ & 2.05 & 5.5 & 2.8 & - & 8.3 \\
\hline Oleic; $\mathrm{C}_{18: 1 \mathrm{n} 10}$ & $0.4-0.5$ & 0.22 & - & - & - & - \\
\hline Oleic; $\mathrm{C}_{18: 1 \mathrm{n} 11}$ & 0.2 & - & - & - & - & - \\
\hline Linoleic; $\mathrm{C}_{18: 2 \mathrm{n} 9,12}$ & $2.8-3.3$ & 1.84 & 7.3 & 4.4 & 4.3 & 4.7 \\
\hline Linolenic; $\mathrm{C}_{18: 3}$ & - & - & 0.5 & 0.2 & - & - \\
\hline $\begin{array}{l}\text { Ricinoleic; } \mathrm{C}_{18: 1 \mathrm{n} 9}, \\
\text { 12-OH }\end{array}$ & $\begin{array}{c}88.1- \\
93.1\end{array}$ & 94.59 & 84.2 & 90.2 & 94.0 & 81.9 \\
\hline Ecosenoic; $\mathrm{C}_{20: 1 \mathrm{n} 11}$ & $0.2-1.5$ & 0.53 & - & - & - & - \\
\hline $\begin{array}{l}\text { Saturated fatty } \\
\text { acids (SFA) }\end{array}$ & $1.5-1.7$ & 0.76 & 2.5 & 1.6 & 1.0 & 5.0 \\
\hline $\begin{array}{l}\text { Unsaturated fatty } \\
\text { acids (UFA) }\end{array}$ & $\begin{array}{c}98.1- \\
98.9\end{array}$ & 99.23 & 97.5 & 97.6 & 98.3 & 94.9 \\
\hline
\end{tabular}

${ }^{\mathrm{a}}$ Panhwar et al. (2016) [18], ${ }^{\mathrm{b}}$ Salimon et al. (2010) [2], ${ }^{\mathrm{c}}$ Conceicao et al. (2007) [4], ${ }^{\mathrm{d}} \mathrm{Gupta}$ et al. (1951) [23], 'Algharib and Kotb (2013) [24]. 


\section{FTIR Analysis of Castor Seed Oil}

The FTIR spectra of castor varieties were nearly similar and no significant difference served as shown in Figure 1. For the identification of functional groups and bands corresponding to various stretching and bending vibrations, which clearly indicates the different characteristic bands of the expected functional groups. The band at $3424 \mathrm{~cm}^{-1}$ represents the $\mathrm{O}-\mathrm{H}$ stretching vibrations which clearly indicate the presence of hydroxylated ricinolic acid (prominent peak of castor oil). The band at $3007 \mathrm{~cm}^{-1}$ represents $-\mathrm{C}-\mathrm{H}$ stretching vibrations of cis- double bond of unsaturation, whereas the band at 2922 and $2855 \mathrm{~cm}^{-1}$ are characteristics of assymetrical and symmetrical vibrations of aliphatic $-\mathrm{CH}_{2}$ fatty acid hydrocarbon chain $[21,22]$. The ester carbonyl $(\mathrm{C}=\mathrm{O})$ functional group shows characteristic stretching band of triglyceride at $1739 \mathrm{~cm}^{-1}$. The bending vibrations of $-\mathrm{CH}_{2}$ scissoring aliphatic groups observed at $1455 \mathrm{~cm}^{-1}$, while the band at 1366 and $1235 \mathrm{~cm}-1$ are due to bending vibration of $-\mathrm{CH}_{2}$ groups. The bands at $1235,1160,1089$ and $1040 \mathrm{~cm}^{-1}$ belongs to bending vibrations of ester carbonyl group. The band at $971 \mathrm{~cm}^{-1}$ reveal the presence of$\mathrm{HC}=\mathrm{CH}-$ (trans) bending out of plane. The band at $858 \mathrm{~cm}^{-1}$ is for $=\mathrm{CH}_{2}$ wagging vibrations . However the band at $719 \mathrm{~cm}^{-1}$ is due to overlapping of $-\mathrm{CH}_{2}$ rocking out of plane vibration of cis-disubstituted olefins, characteristics of long chain fatty acids.
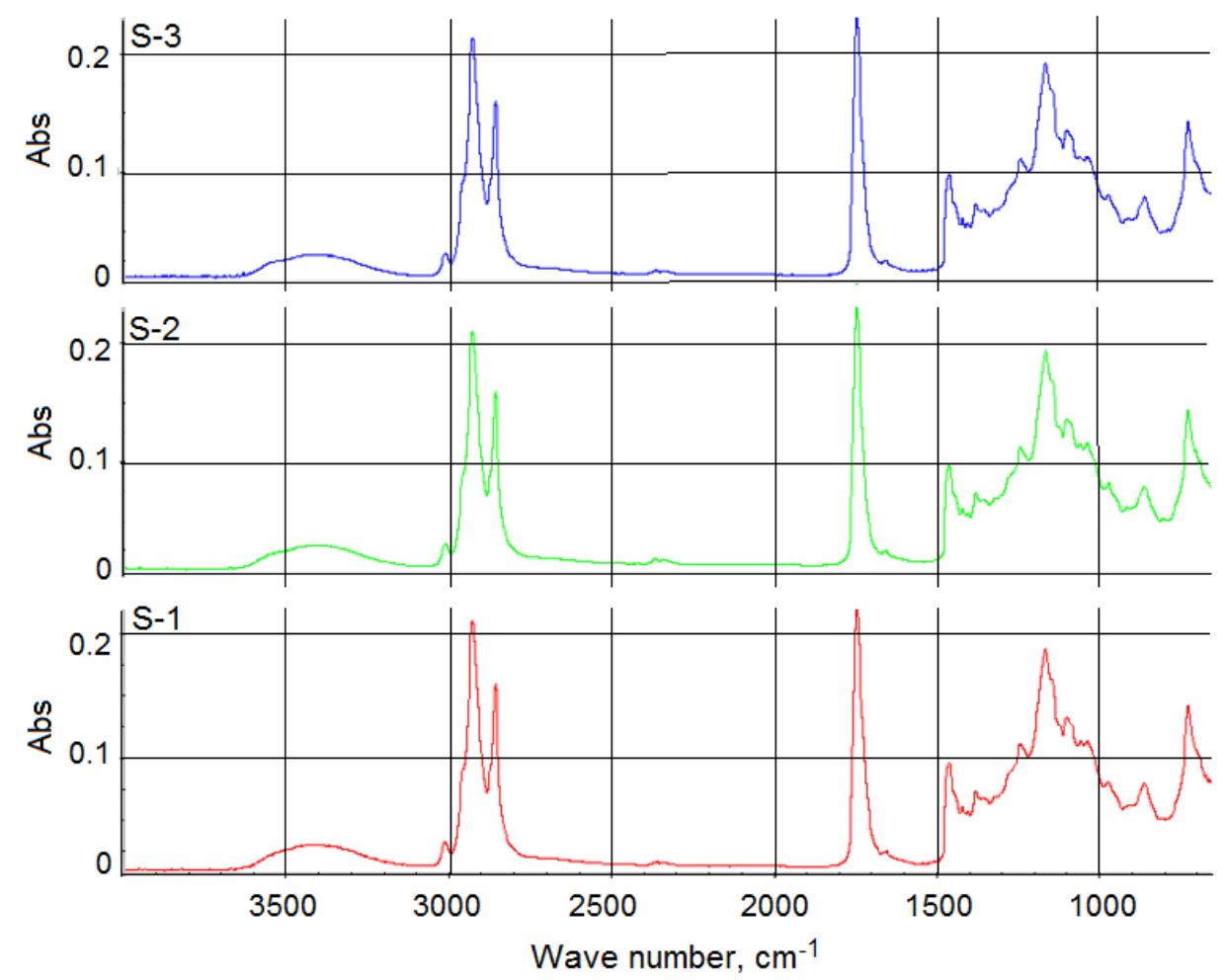

Figure 1. FTR Spectra of three castor seed oil varieties 


\section{Correlation of IR band intensity with physicochemical properties of castor oil}

As mentioned earlier that no significant differences was observed in the spectra of castor seed varieties. On careful examination of the intensity values of each functional group present in the oil showed some variations in castor seed varieties as shown in Table 5. Therefore, attempt was made to correlate the intensities of different functional groups with the physiochemical properties of castor oil. The band at $3421 \mathrm{~cm}^{-1}$ showed correlation with the values of specific gravity as it can be seen from Table 2. The highest specific gravity was observed in S-2 and lowest in S-1, similarly higher intensity was observed in S-2 and lower in S-1. FFA showed correlation with the intensity of band at $3007 \mathrm{~cm}^{-1}$ as it can be seen from Table 2, the highest FFA was noted in S-3 and lower in S-1. Usually band at $1709 \mathrm{~cm}^{-1}$ has been reported for FFA determination. As this band is completely absent in all castor varieties, therefore band at $3007 \mathrm{~cm}^{-1}$ was selected. The band at $1742 \mathrm{~cm}^{-1}$ was linked with the SV of castor oil. Higher and lower SV was observed in S-2 and S-3 variety, similarly higher and lower intensities were also observed in S-2 and S-3, respectively. Table 2 further shows highest values of IV in S-2 variety and lowest IV in S-3, likewise IV was correlated with the intensity of band at $1652 \mathrm{~cm}^{-1}$. It is well known fact that castor oil show high values of viscosity. Among three varieties, highest viscosity was observed in S-2, while lowest in S-3 variety. These viscosity values highly correlated with the intensity of band at $1457 \mathrm{~cm}^{-1}$, which showed similar trend. The band at $1377 \mathrm{~cm}^{-1}$ showed correlation with the values of refractive index. The highest and lowest refractive index value was observed in S-3 and S-1, similarly higher intensity was observed in S-2 and lower in S-1, respectively. PV also showed correlation with two infrared bands at $1161 \mathrm{~cm}^{-1}$ and $1096 \mathrm{~cm}^{-1}$. As it can be seen from Table 2, that highest PV was observed in S-1 and lowest in S-3. Similar trend in higher and lower intensity was observed in S-1 and S-3.

FTIR spectral intensity of functional groups of castor seed oil

Table 5

\begin{tabular}{|c|c|c|c|c|c|}
\hline \multirow{2}{*}{ S.No. } & \multirow{2}{*}{$\begin{array}{l}\text { Frequency } \\
\left(\mathrm{cm}^{-1}\right)\end{array}$} & \multicolumn{3}{|c|}{ Intensity } & \multirow{2}{*}{ Observation } \\
\hline & & S1 & $\mathrm{S} 2$ & S3 & \\
\hline 1 & 3421 & 0.0273 & 0.0279 & 0.0276 & $\mathrm{O}-\mathrm{H}$ stretching \\
\hline 2 & 3007 & 0.0288 & 0.0293 & 0.0297 & $\begin{array}{l}\text { C-H stretching vibration of the cis- } \\
\text { double bond }(=\mathrm{CH})\end{array}$ \\
\hline 3 & 2923 & 0.212 & 0.213 & 0.210 & $\mathrm{CH}_{2}$ Asymmetrical stretching \\
\hline 4 & 2853 & 0.159 & 0.159 & 0.158 & $\mathrm{CH}_{2}$ Symmetrical stretching \\
\hline 5 & 1742 & 0.232 & 0.233 & 0.221 & $\mathrm{C}=\mathrm{O}$ stretching \\
\hline 6 & 1652 & 0.0232 & 0.0240 & 0.0226 & $\mathrm{C}=\mathrm{C}$ Stretching \\
\hline 7 & 1457 & 0.0958 & 0.0972 & 0.0945 & $\mathrm{CH}_{2}$ Scissors \\
\hline 8 & 1377 & 0.0714 & 0.0716 & 0.0718 & Bending vibration of $\mathrm{CH}_{2}$ groups \\
\hline 9 & 1239 & 0.109 & 0.110 & 0.110 & \multirow{4}{*}{ Vibrations of the $\mathrm{C}-\mathrm{O}$ ester groups } \\
\hline 10 & 1161 & 0.193 & 0.192 & 0.188 & \\
\hline 11 & 1096 & 0.136 & 0.135 & 0.131 & \\
\hline 12 & 1031 & 0.112 & 0.111 & 0.112 & \\
\hline 13 & 965 & 0.0784 & 0.0789 & 0.0789 & $\begin{array}{l}\mathrm{CH}=\mathrm{CH} \text { (trans) bending out of } \\
\text { plane }\end{array}$ \\
\hline 14 & 858 & 0.0765 & 0.0771 & 0.0777 & $=\mathrm{CH}_{2} \quad$ Wagging \\
\hline 15 & 723 & 0.140 & 0.141 & 0.141 & $\begin{array}{l}\text { Overlapping of the } \mathrm{CH}_{2} \text { rocking } \\
\text { vibration and the out-of-plane } \\
\text { vibration of } c i s \text {-disubstituted olefins }\end{array}$ \\
\hline
\end{tabular}




\section{Conclusion}

The current investigation on indigenous local castor seed varieties encourages their commercialization to increase economic growth at national level. A complete profile of local varieties showed sufficient oil content (44-48\%). Fatty acid examination by GCMS has shown ricinoleic acid in high percentage. Some unusual fatty acids like isomers of oleic acid and eicosenoic acid were also determined and reported in local varieties from this region. FTIR study revealed the correlation of band intensities with physiochemical characteristics of castor seed oil such as specific gravity, free fatty acids, saponification value, iodine value, viscosity, refractive index and peroxide value.

Acknowledgments. The National Centre of Excellence in Analytical Chemistry, University of Sindh, Jamshoro, Pakistan is gratefully acknowledged for the financial support. The authors also would like to thank Higher Education Commission (HEC), Pakistan.

\section{References}

1. Ramanjaneyulu A.V., Reddy A.V., Madhavi A. (2013), The impact of sowing date and irrigation regime on castor (Ricinuscommunis L.) seed yield, oil quality characteristics and fatty acid composition during post rainy season in South India, Ind. Crops Prod, 44, pp. 25-31.

2. Salimon J., Noor D.A.M., Nazrizawati A.T., Firdaus M.Y.M., Noraishah A. (2010), Fatty Acid Composition and Physicochemical Properties of Malaysian Castor Bean Ricinuscommunis L. Seed Oil, Sains Malaysiana, 39(5), pp. 761-764.

3. Ogunniyi D.S. (2006), Castor oil: A vital industrial raw material, Biores. Technol, 97, pp. 1086-1091.

4. Conceição M.M., Candeia R.A., Silva F.C., Bezerra A.F., Fernandes, Jr V.J., Souza A.G. (2007), Thermoanalytical characterization of castor oil biodiesel, Renew. Sust. Energ. Rev, 11, pp. 964-975.

5. Perdomo F.A., Acosta-Osorio A.A., Herrera G., Vasco-Leal J.F., Mosquera-Artamonov J.D., Millan-Malo B., Rodriguez-Garcia M.E. (2013), Physicochemical characterization of seven Mexican Ricinuscommunis L. seeds \&amp; oil contents, Biomass Bioenerg, 48, pp. 17-24.

6. Berman P., Nizri S., Wiesman Z. (2011), Castor oil biodiesel and its blends as alternative fuel, Biomass Bioenerg, 35, pp. 2861-2866.

7. Amara A.A., Salem S.R. (2009), Dehydration of castor oil and lipase production by pseudomonas aeruginosa, American-Eurasian J. Agric. Environ. Sci, 5(4), pp. 556-563.

8. Damodaram T., Hegde D.M. (2011), Oilseeds Situation: A Statistical Compendium, Directorate of Oilseeds Research, Hyderabad.

9. Khan N.A., Dessouky H. (2009), Prospect of biodiesel in Pakistan, Renew. Sust. Energy Rev, 13, pp. 1576-1583.

10. Cheema N.A., Farooq U., Shabbir G., Shah M.K.N., Musa M. (2013), Prospects of castor bean cultivation in rainfed tract of Pakistan, Pak. J. Bot, 45(1), pp. 219-224.

11. Soil Survey of Pakistan, Available at: www.pakistan.gov.pk/divisions/food-division. 
12. Chakrabarti M.H., Ahmad R. (2008), Transesterification studies on castor oil as a first step towards its use in Bio Diesel production, Pak. J. Bot, 40(3), pp. 1153-1157.

13. Akpan U.G., Jimoh A., Mohammed A.D. (2006), Extraction, Characterization and Modification of Castor Seed Oil, Leonardo J. Sci, 8, pp. 43-52.

14. AOCS. (2013), Firestone D. $6^{\text {th }}$ Edition. Official Methods of Analysis, Association of Analytical Chemistry, Inc. Arlington, USA.

15. Nikovska K., Stefanova S., Stefanov L., Damyanova S., Stoyanova A., Gubenia O. (2017), Influence of adding of laurel essential oil extracts on salad dressings properties, Ukrainian Food Journal, 6(3), pp. 433-442.

16. International Union of Pure and Applied Chemistry. (1992), Standards methods for the analysis of oils, fats and derivatives, $7^{\text {th }}$ edition. Alden Press, Oxford.

17. Cheema N.M. (2011), Yield and chemical composition of castor bean (Ricinuscommunis L.) as influenced by environment, Ph.D. thesis UAAR, Rawlpindi, Pakistan.

18. Panhwar T., Mahesar S.A., Mahesar A.W., Kandhro A.A., Talpur F.N., Laghari Z.H., Chang A.S., Sherazi S.T.H. (2016), Characteristics and composition of high oil yielding castor variety from Pakistan, J. Oleo Sci, 65(6) pp. 471-476.

19. Kandhro A., Sherazi S.T.H., Mahesar S.A., Bhanger M.I., Talpur M.Y., Arain S. (2008), Monitoring of Fat Content, Free Fatty Acid and Fatty Acid Profile Including trans Fat in Pakistani Biscuits, J. Am. Oil Chem. Soc, 85, pp. 1057-1061.

20. Nangbes J.G., Nvau J.B., Buba W.M., Zukdimma A.N. (2013), Extraction and Characterization of Castor (RicinusCommunis) Seed Oil, Int. J. Eng. Sci, 2, pp. 105109.

21. Mahesar S.A., Sherazi S.T.H., Kandhro A.A., Bhanger M.I., Khaskheli A.R., Talpur M.Y. (2011), Evaluation of important fatty acid ratios in poultry feed lipids by ATR FTIR-spectroscopy, Vibr. Spectrosc, 57.

22. Sherazi S.T.H., Kandhro A., Mahesar S.A., Bhanger M.I., Talpur M.Y., Arain S. (2009), Application of transmission FT-IR spectroscopy for the trans fat determination in the industrially processed edible oils, Food Chem, 114, pp. 323-327.

23. Gupta S.S., Hilditch T.P., Riley J.P. (1951), The Fatty Acids and Glycerides of Castor Oil, J. Sci. Food Agric, 2(6), pp. 245-251.

24. Algharib A.M., Kotb E.A. (2013), Biodiversity of castor bean in Egypt for the potential possibility of using as a bioenergy crop, The 3rd International Conference on: Neglected and Underutilized Species (NUS): for a Food-Secure Africa Accra, Ghana, 25-27 September 2013. 